\title{
Personnel Management in NGOs of Bangladesh
}

\author{
Khondaker Mizanur Rahman \\ Nanzan University \\ E-Mail: kmrahman@nanzan-u.ac.jp \\ Maksuda Sultana \\ BRAC Advocacy for Social Change \\ E-Mail:dn_sultana@yahoo.co.uk
}

\begin{abstract}
Activities of non-governmental organizations (NGOs) in Bangladesh have gained momentum due to the failure of both governmental organizations (GOs) and for-profit organizations (FPOs) in achieving their mission and objectives, and thus their inability to fulfill needs of the beneficiaries/customers. Prima facie investigations show that little research has been done on the personnel management of NGOs in Bangladesh. In view of this situation, using a mixed method of survey of archival sources, quantitative review of job advertisements data, unstructured interview, and a case study, this research examines personnel management practice of NGOs, and explores basic characteristics in the three areas of personnel selection and recruitment, training and education, and compensation and motivation. The findings suggest that large NGOs implement systematic practices, possess adequate organizational structure, employ professional managers, and nurture pragmatic environments for their personnel management. The NGOs emphasize professionalism and career orientation and implement long-term, forward-looking approaches in their selection, recruitment, and remuneration. These management practices also follow national employment practices, attach importance to national wage and salary principles, policies, and scales for the GO/FPOs, but formulate their principles and systems keeping those in view. The international NGOs (INGOs) follow domestic practices, implement policies and practices of their own which is found to create confusion in the national job market. The small and mid-size NGOs, however, do not possess personnel management practices of their own, rather they follow and imitate larger members. The authors envision further research on this topic with a focus on both of its micro
\end{abstract}


and macro aspects, and use of advanced methods and tools to develop a full model of NGO-human resources management (HRM) in Bangladesh.

Keywords: Bangladesh, Personnel Management, NGOs, Job Advertisement, Job Notification, Recruitment, Remuneration, Selection

\section{INTRODUCTION}

Bangladesh has turned into a nation of NGOs, and it is argued humorously that in terms of the number of NGOs for every ten thousand people, Bangladesh ranks number one in the world. NGO activities in this country have gained momentum due to the failure of both the GOs and FPOs to achieve their missions and objectives, which were to fulfill their responsibilities to their customers, beneficiaries, and stakeholders (Farrington \& Bebbington, 1993; Nobusue, 2002; Ray, 1983; Siddiqui, 1996). Consequently, NGOs have emerged as an alternative solution to the needs of the market and society. NGO activities occur in economic development, and poverty alleviation through employment creation, micro-credit, gender disparity eradication, education, community building, human rights protection and advocacy, social and environmental development, marginally placed and outreach communities protection, and salvation from destitution, have generated enormous success as demonstrated by the awarding of the Nobel Peace Prize to the Grameen Bank and its founder in 2006 (Khondaker, Bhuiyan, Runa, Khanam, Nahar, Hossain, \& Khoda, 2007; Holloway, 1998; Yunus, 2000; Potter \& Ahmed, 2005). Consequent to this epoch-making incident, the activities of NGOs have gained further impetus. Innumerable NGOs have been founded to organize and implement developmental projects and activities throughout the country. Researchers and practitioners from home and abroad have also heightened their interests in researching NGOs from broader perspectives (Farrington \& Bebbington, 1993; Farrington \& Lewis, 1993; Anaheier \& Salamon, 1998; Holloway, 1998; Khan, 2003; White, 1991; Potter and Ahmed, 2005).

However, literature review indicates that little research has been done to date on personnel management of NGOs and its various domains. In view of this, this paper examines personnel management of NGOs in Bangladesh to explore its basic characteristics in the three selected areas of selection and recruitment, training and education, and compensation and motivation of the staff, volunteers, and managers. The assumption prima facie is, if the basic characteristics of management in these three areas are known, that it will enlighten the research community on both micro and macro domains using advanced methods and techniques, and will help develop a full model of NGO-HRM in Bangladesh. 
This paper proceeds as follows. First, it introduces the research objectives and scope as described above, and then conducts a literature survey of the general features of personnel management in NGOs and non-profit organizations (NPOs). Then, after explaining the research organization and method, it examines the different aspects of personnel management practices in the Bangladeshi NGOs, as found in the analysis of the results and findings. In this section, it elucidates some specific examples and the case of the Bangladesh Rural Advancement Committee (BRAC), the biggest NGO in the country. Finally, it summarizes and generalizes the overall research findings, and explores the implications of this research.

\section{PERSONNEL MANAGEMENT IN NGOs: LITERATURE SURVEY}

\section{General}

Time and place, mission, goals, and objectives greatly shape and influence the nature and practice of personnel management in NGOs (Butler \& Wilson, 1990; Drucker, 1992; Oster, 1995; Legge, 1995; Cunningham, 1999). Compared with FPOs and GOs sectors, the degree of labor intensity is very high in some NGOs (in particular, religious institutions and philanthropic organizations). Unlike FPOs and GOs, an NGO's human forces consist of three categories, namely honorary/paid board members, professional manager/staff, and volunteers. Volunteers, paid staff and managers, and paid board members are regarded as "critical stakeholder" (Oster, 1995). Private and institutional donors and governments exercise significant influence on the governance and personnel management in many such organizations (Birchall \& Simmons, 2004; Cornforth, 2004; Low, 2006).

Like FPOs and GOs, the success or failure of an NGO depends on its ability to procure a high quality human resources, training, education, and developing these resources through the adoption of efficient management practices. A dedicated and high quality human force is also essentially needed for translating the mission and goals into action. Although it is difficult to evaluate skills and performance of people in some organizations, many NGOs give their people well-defined goals and objectives, assign them to challenging projects, and evaluate performance in terms of achievement of such assigned objectives, goals, and projects (Drucker, 1992).

Similar to FPOs, the top echelon of management in an NGO is its board or executive committee, which usually consists of representatives of donors, promoters, community representatives, socially respectable people, learned people, business people, members of professional bodies like lawyers' and doctors' associations, and representatives of different benefactors (Byrd \& Hickman, 1992; Flectcher, 1992; 
Gosh \& Sirmans, 2005). Social and religious organizations are normally run by social workers; educational institutions by former teachers or alumni or founders or donors. NGOs engaged in economic developmental activities and social welfare activities often employ professionally experienced people on the board and in executive positions, but vocational skill development institutions depend more on experienced and skill-holding paid professional executives (Birchall \& Simmons, 2004; Cornforth, 2004; Low, 2006). Top management in such types of NGOs can be stylized as "professional bureaucracy", whereby professional codes of conduct and operational policies developed outside the organization strongly influence activities of management and staff. However, delegation of authority and responsibility and span of control are well articulated in such organizations (Drucker, 1992).

Boards of NGOs are generally larger than those in GOs and FPOs, and consist of mostly outsiders, who are drawn from heterogeneous sources, as mentioned above. Insiders (promotion from within) are less favored, since strong safeguards against board hegemony is not always available from people considered as insiders (Rosenstein \& Wyatt, 1990; Drucker, 1992; Oster, 1995). A board's tenure of office is relatively shorter than GOs and FPOs; and this is done mainly to check any signs of dictatorial power of the chief executive director and his/her team. While board members and executives in the larger NPOs are mostly involved in creating social liaison and fundraising, in small NPOs they also are involved in day-to-day management activities (Butler \& Wilson, 1990; Drucker, 1992; Oster, 1995; Legge, 1995; Cunningham, 1999).

Boards perform five important functions, such as, selection and evaluation of the chief executive officer (CEO), defining and re-evaluating of mission of the organization, development of policy, plan, and strategy for the organization, approval of budget, and procurement of funds and resources (Oster, 1995). Thus, the very high level strategic decisions are kept within the board's jurisdiction. Theoretically, an NPO board plays protective and supervisory roles like those in the FPOs. In reality, board members are "boundary-spanners" and "organizational go-betweens", and exercise both operating and strategic functions (Oster, 1995). A large size and an unbalanced composition, however, can give rise to dissension and discord, increase tension within the board, and bring negative impact on the efficiency of operation and management (Byrd \& Hickman, 1992; Legge, 1995; Oster, 1995; Cunningham, 1999). An effective board possesses "a shared vision, often developed by strategic planning efforts, a tolerance for conflict coupled with an ability to control it, a strong committee system to manage size, and a strong core working group" (Oster, 1995). 
Next is the question of management of the volunteers, who in many NGOs play an important role in propagating the mission, raising funds, and achieving goals and objectives (Armstrong, 1992; Wilson \& Pimm, 1996; Zimmeck, 1998; Cunningham, 2001). Although volunteers fall outside the mainstream of paid staff and employees, there is a need for utmost care in their selection and appointment, and putting them into action as they often represent the "public face" of the NGO. In social services and religious NGOs, volunteers sometime constitute the mainstay of the human force. These categories of NPOs design hierarchies with specified qualification, experience, and on-the-job achievement to promote volunteers, and provide them training and education. Volunteers work for both altruistic and self-interested motives (Butler \& Wilson, 1990; Legge, 1995; Oster, 1995; Cunningham, 2001). The self-interest motive mostly relates to gaining experience and skills for a career, and is called investment gains. The altruistic motive relates to helping the employer organization achieve its mission and goals, and thereby receive benefits from it (Oster, 1995). This is also called "consumption gains". However, it is true that people who once work as volunteers may later pursue a career in the NPO sector, and ultimately turn into a donor or felicitator or customer of services. Many volunteers become an ambassador of goodwill for their employers. Wherever they pursue income-earning careers, their volunteer mentality remains dormant, and may reawaken at any point of life. For this reason, adequate caring and nurturing of volunteers with long-range goals is treated as one of the most important aspects of personnel management in many large-scale NGOs (Drucker, 1992; Oster, 1995).

Research evidence indicates that NGOs offer cheaper compensation packages to professionals and staff than that offered by FPOs and GOs (Butler \& Wilson, 1990; Hudson, 1999; Barros \& Gomes Santos, 2003; Barros, 2006). Those engaged in social services, community-based activities, religious organizations, and educational institutions mostly get cost-free services from top executives who join such organizations, with the motive of service to the community (Ott, 2001). Even if board members come from active services or are retired people from FPOs and GOs, mostly they consider their service as a contribution to society or humanity. However, international NGOs offer higher wages and other benefits in less-developed countries (LDCs) (Stiles, 2002), and it is still un-researched whether multinational business enterprises offer better remuneration packages in those countries than NGOs or other international funding organizations.

Incentive wages seen in FPOs are rare in NGOs, because such incentive-wage schemes contradict their ideological aspect of service, and also do not match well with 
their institutional image and nature. Even if job requirements, job contents, and other factors vary between male and female, gender-based wage differentials are less visible in NGOs. Workers, as observed in many cases, donate or forego a part of their wages to support the employers' mission or as their own ideological commitment. Also, job requirements and performance evaluation are more lenient in NPOs than FPOs. Staff and workers are given considerable freedom of self-actualization by planning their jobs and making implementation decisions (Butler \& Wilson, 1990; Drucker, 1992; Oster, 1995; Legge, 1995; Cunningham, 1999; Hudson, 1999; Zacharias, 2003).

\section{In Bangladesh}

Bangladesh has turned into a country of NGOs, and it is humorously argued that the number of NGOs for every ten thousand people in this country could be the highest in the world, or at least in developing countries. The NGO sector with 40-65 thousand member organizations, both registered and non-registered, is the biggest employer in this country (Daily Ittefaq, 2009; NGO Affairs Bureau (NGOAB)/Government of Bangladesh (GOB), 2009; Register of Companies (ROC)/GOB, 2009; Khondaker, Molla, \& Rahman, 2008; Potter, 2009), and employs people as paid and honorary staff, professional management, consultant, and volunteers. The Association of Development Agencies of Bangladesh (ADAB), an apex organization of local, national, and foreign NGOs, show that its affiliated 567 NGOs employed 121,193 people, including 26,021 (21.5\%) full-time, and 15,803 (13.0\%) part-time, and 79,369 (65.5\%) volunteers in July 1998. The male-female distribution of this employment was 76,182 or (62.8\%) and 45,011 (37.1\%), respectively (ADAB, 2000). Given that Bangladesh has a male-dominated labor market, this high rate of female employment is significantly ambitious and encouraging, in that NGOs are playing decisive roles in creating female friendly job market in this country. At present, the size of employment in all NGOs might be several-hundred times more than the quoted above, and this sector is said to the single largest employer in the country. BRAC alone employs more than 115,000 people (BRAC, 2008). Some welfare organizations employ volunteers in promoting their activities in the remotely located and difficult-to-reach communities (ADAB, 2000).

Developmental large NGOs, namely BRAC, Grameen Bank (in its non-banking and nonprofit micro-credit activities), Association of Social Advancement (ASA) and Nijera Kori, and INGOs employ people mostly on a full-time basis. Although there exists no formal rule and law to regulate and govern recruitment, employment, other job-related terms and conditions, especially large NGOs have developed personnel 
management policies of their own, keeping in view the employment rules and laws that prevail in the country for government and private sector organizations and enterprises. The major rules for the private sector are as follows: Factories Act, Workers Compensation Act, National Wage Boards Regulation; and, those for the public sector are Government Employees Service Rules, Public Sector Employment and Service Rules, and National Pay Commission's Regulations (Khondaker, 1997). NGOs derive essence from these rules in that they keep their wages and salaries the same or above the national minimum levels, follow terms and conditions on probation and permanency in job, provide similar or better facilities of welfare, and avoid conflict and confusion concerning terms and conditions of employment (Khondaker, 2006). Even though NGOs are federated into forums of different types, their staff and managers are not organized into trade unions. Therefore, most employment related problems and conflicts are settled through direct negotiation between the employer and the aggrieved person (Khondaker, 2006).

Innumerable studies on NGOs in Bangladesh focus on issues of micro-credit, job formation, sustainable development, women's issues, social and economic issues, NGO interrelationships, NGOs-GOs-FPOs interface, project development and implementation issues, and project efficiency, etc., but do not deal much with issues on personnel management (Ray, 1983; White, 1991; Farrington \& Bebbington, 1993; Farrington \& Lewis, 1993; Farrington \& Bebbington, 1993; Siddiqui, 1996; Holloway, 1998; Anaheier \& Salamon, 1998; Holloway, 1998; Yunus, 2000; Nobusue, 2002; Khan, 2003; Potter \& Ahmed, 2005; Khondaker, 2006; Khondaker, Bhuiyan, Runa, Khanam, Nahar, Hossain, \& Khoda, 2007; Potter, 2009).

Of the four Ms of management - man, material, money, and method management of man, in other words, personnel management in Bangladesh, is still of minor importance due to the huge human resource supply. Most research in NGOs' personnel management relates to job conditions in field-level positions or females in low-level and staff positions (Alam, 1998; Begum, 1993; Goetz, 1995, 1997; Hashemi \& Hossain, 1995). Ahmad (2007) reported NGO field-workers as reluctant employees, who mostly leave jobs when they grow older, or find stable employment in government and private sectors, or women who marry and subsequently leave employment. Carrier development, opportunity of progression in the hierarchy, and status in grass-roots level jobs are extremely ambiguous (Goetz, 1995). These and similar studies bring to light the weak points of management in specific aspects, but do not reveal a comprehensive picture of personnel management and its generalized posture. 
In order to solve employment-related grievances, there exists labor courts and labor appellate tribunals. NGO employees can file litigation charges with them, and receive verdicts on employment-related grievances (GOB/Ministry of Labour or MOL, 1965; Khondaker, 1997). Examples of employment and wage and salary-related cases in these courts are, however, almost non-existent in terms of references. In most cases, NGOs manage employment, promotion, transfer, and retirement without much conflict, and if any grievance arises, it is solved amicably (Khondaker, 2006). NGOs negotiate with the employers of GOs and FPOs to nurture a healthy employment market and rational job conditions in the country. Within their own frameworks, they foster good practices so that they can work on behalf of other people in need (Khondaker, 2006). One recent conflict, which was brought to court, was that of Proshika's malaise in its governing board (Daily Ittefaq, 2009).

From this literature survey, it is evident that although rich resources of literature exist on general aspects of NGOs, and personnel management of NGOs/NPOs in other countries, but in the case of Bangladesh NGOs, research is still almost non-existent on selection and recruitment, placement and promotion, training and education, compensation and motivation, performance appraisal, career development, and many other sub-domains of management. NGOs follow the trend of personnel management in FPOs and GOs. We assume that personnel management in these organizations, especially employment, remuneration, and motivation practices, is reflected in their instruments of positions announcement (advertisement and notification), and a methodical and well-organized examination can reveal those.

\section{RESEARCH METHOD AND ORGANIZATION}

Methods used in this research are a mixture of archival sources survey, quantitative review of job data of 240 randomly selected employment advertisements and notifications (Daily Janakantha, 2006; Daily Ittefaq, 2009; Imageshack, 2009; Prothom Alo, 2009), and an unstructured interview of 30 selected NGO-knowledgeable people (NGO leaders, activists, researchers, and government administrators). Inductive and deductive approaches have been used for the analyses and interpretations, but these do not apply advanced empirical research models and tools. This mixed method was applied to cross-examine and authenticate the findings, especially from the investigation of the employment advertisements and notifications.

Based on the literature survey of personnel management in Bangladesh, we developed a checklist of 52 items divided into 14 categories. The categories include job title, personnel management authority, mode of job notification, selection process, 
academic qualification requirement, previous job experience, skill preference, job description, certification and evidence, training and education, mode of employment, remuneration package, job location, and career opportunity. These items and categories are listed in Table 1. After the initial tabulation of the items with frequency analysis, we calculated percentages and applied quantitative inferences to determine the importance of each item. However, a general picture of Bangladeshi NGO-personnel management is deduced by combining findings from the above mentioned two other techniques.

The 240 job advertisements and notifications were collected on 180 NGOs - of which 160 are national and the rest 20 are international - and were published in various newspapers in 2007, 2008, and 2009 (Imageshack, 2009). We also examined all 57 small-NGOs in the three union parishods (the grass-roots level administrative unit in the country) of the Uzirpur Union Council, Kalikapur Union Council, and Kashinagar Union Council in Chouddagram Upazela, and East Zorkaran Union Council of Kotowali Thana through selected contact persons. This region was selected for investigation for its easy access by the Dhaka-Chittagong Grand Trunk Road, ease in getting contact persons, and the regions long and affluent history of non-governmental and nonprofit grassroots level developmental activities since the time of Akhter Hameed Khan, the pioneer of cooperative movement in Bangladesh in the 1970s.

The process of selection of the sample NGOs/job advertisements were eclectic, in that, we wanted to see the personnel management practices of large national and INGOs that have long histories, manage activities and projects on a wide scale, possess sound personnel management policies and organizations, and are registered. The small NGOs apparently do not meet these criteria, but we included them in the study to determine if they would introduce any personnel management practices.

\section{RESULTS AND FINDINGS}

The analysis of results and findings here focus on the three areas, namely selection and recruitment, training and education, and remuneration and motivation, and are earmarked for research in this project and described in the Introduction.

\section{Analysis of Job Advertisements and Notifications}

We tabulated the frequencies of each sub-item and deduced their importance by calculating percentage (Table 1). Large-scale national NGOs possess personnel management divisions within their organizational frameworks (91.6\%), and employ 
people with extensive knowledge on employment policies and procedures and development of personnel management strategies in relation to the mission and vision of the organization. For all official and managerial positions, employers need experiences in line with the job requirements (100\%); 35\% seek experience in private sector, and $25 \%$ seek experience in GOs. Job seekers are required to have standard skills in computer literacy, and excellent communication skills in Bengali (national language) and English (60\%). All expect mental readiness to work in developmental organizations (100\%). Applicants are discerned to be energetic, self-motivated, and generous individuals, and hold a robust "can-do" attitude toward activities of developmental organizations. NGOs that do not have personnel management divisions develop departments or sections to look after personnel management (8\%); and, those that do not have such organizational units establish administration or general affairs divisions to manage personnel management activities (33\%).

NGOs use unambiguous job titles, some of which apparently denote very big designations, and can give an incorrect impression to people (Khondaker, Molla, \& Rahman, 2008). They recruit their staff and managers directly (100\%); place advertisements and notifications mostly in the newspapers (100\%), which is the most popular method of job-search and employment in the country.

Table 1 NGOs' Personnel Management Characteristics in Job Advertisements and Notifications

$(\mathrm{N}=240 ; \%$ is calculated as number of NGOs citing an item $\div$ total population $\mathrm{x} 100)$

\begin{tabular}{lcc}
\hline \multicolumn{1}{c}{ Aspects of Personnel Management Visible in Advertisement/Notice } & Frequency & Percent \\
\hline Job title & & \\
\hline -very clear & 240 & 100.0 \\
\hline -not clear & 0 & 0 \\
\hline Job description & 240 & 100.0 \\
\hline -very clear & 0 & 0 \\
\hline -not clear & & \\
\hline Personnel management authority & 140 & 58.3 \\
\hline -human resource department & 80 & 33.3 \\
\hline -administration division & 20 & 8.3 \\
\hline -other
\end{tabular}

Note: Items mentioned in this table do not add to $100 \%$. Employers attach different importance to each item, and therefore, we exercised our judgment in selecting the important items. 
Table 1 NGOs’ Personnel Management Characteristics in Job Advertisements and Notifications (Continued)

$(\mathrm{N}=240 ; \%$ is calculated as number of NGOs citing an item $\div$ total population $\mathrm{x} 100)$

\begin{tabular}{|c|c|c|}
\hline Aspects of Personnel Management Visible in Advertisement/Notice & Frequency & Percent \\
\hline \multicolumn{3}{|l|}{ Method of job ad and notification } \\
\hline -newspaper & 240 & 100.0 \\
\hline -web sites & 72 & 30.0 \\
\hline -employers' notice board & 4 & 1.7 \\
\hline \multicolumn{3}{|l|}{ Selection process } \\
\hline -written exam & 20 & 8.5 \\
\hline -short-listing and interview & 60 & 25.0 \\
\hline -interview & 240 & 100.0 \\
\hline -references & 16 & 6.7 \\
\hline \multicolumn{3}{|l|}{ Academic qualification } \\
\hline -specific major and university & 72 & 30.0 \\
\hline -specific education level & 240 & 100.0 \\
\hline -training and certificate & 84 & 35.0 \\
\hline \multicolumn{3}{|l|}{ Certificate and evidence needed } \\
\hline -forwarding letter & 240 & 100.0 \\
\hline -curriculum vitae & 240 & 100.0 \\
\hline -academic qualification & 240 & 100.0 \\
\hline -experience certificate & 112 & 46.7 \\
\hline -photograph & 240 & 100.0 \\
\hline -national identity card & 20 & 8.3 \\
\hline \multicolumn{3}{|l|}{ Type of employment } \\
\hline -long-term/permanent & 28 & 11.7 \\
\hline -contractual and extendable & 168 & 70.0 \\
\hline -project duration & 44 & 18.3 \\
\hline \multicolumn{3}{|l|}{ Job experience } \\
\hline -similar jobs & 240 & 100.0 \\
\hline -in NGOs & 60 & 25.0 \\
\hline -in government organization & 20 & 8.3 \\
\hline -in private sector organization & 84 & 35.0 \\
\hline
\end{tabular}

Note: Items mentioned in this table do not add to $100 \%$. Employers attach different importance to each item, and therefore, we exercised our judgment in selecting the important items. 
Table 1 NGOs' Personnel Management Characteristics in Job Advertisements and Notifications (Continued)

$(\mathrm{N}=240 ; \%$ is calculated as number of NGOs citing an item $\div$ total population $\mathrm{x} 100)$

Aspects of Personnel Management Visible in Advertisement/Notice Frequency Percent

\section{Skills needed}

\begin{tabular}{lcc}
\hline -mental readiness & 240 & 100.0 \\
\hline -job-specific skill & 208 & 86.7 \\
\hline -general skill & 152 & 63.3 \\
\hline -computer skill & 72 & 30.0 \\
\hline -communication skill & 144 & 60.0 \\
\hline -language skill & 72 & 30.0 \\
\hline Training and education & & \\
\hline -orientation & 240 & 100.0 \\
\hline -grassroots level activity & 168 & 70.0 \\
\hline -given on the job as needed & 12 & 5.0 \\
\hline -staff/employee go for own training & 28 & 11.7 \\
\hline Salary and other benefits & & \\
\hline -basic salary & 32 & 13.3 \\
\hline -gross salary & 208 & 86.7 \\
\hline -annual increment & 32 & 13.3 \\
\hline -festival bonus & 120 & 50.0 \\
\hline -contributory provident fund & 32 & 13.3 \\
\hline -gratuity/pension & 12 & 5.0 \\
\hline -insurance & 72 & 30.0 \\
\hline -traveling allowance & 112 & 40.7 \\
\hline -group provident fund & 32 & 13.3 \\
\hline Placement location & 228 & 95.0 \\
\hline -fixed place and clearly mentioned & 12 & 5.0 \\
\hline -frequently transferable job & 20 & 27.5 \\
\hline Career opportunity & 144 & 60.0 \\
\hline -promotion facilities available & & \\
\hline -job term finishes if the project ends & & \\
\hline -promotion and new contract available & & \\
\hline
\end{tabular}

Note: Items mentioned in this table do not add to $100 \%$. Employers attach different importance to each item, and therefore, we exercised our judgment in selecting the important items. 
As computer technology is booming in this country, prominent NGOs open their websites, and post job advertisements in those websites (30\%).

As the method of selection and recruitment, interview and examination of their qualifications and experience-supportive documents are the most important (100\%). Reputed NGOs and INGOs, instead of interviewing all applicants, make short-lists of candidates on the basis of examining applications and documents, and interview only the short-listed candidates (25\%). During the interview, employers give attention to understand personality of applicants and attitude toward developmental organizations and activities, and check documents and certificates of qualification and experience. During the selection process, the employer wants to understand whether the applicant will be able to contribute to jobs without much training, possesses a flexible and agile personality, and holds skills to communicate with different people and organizations, such as, government agencies, local government representatives, private individuals, and community organizers, and especially their mental make-up to work in the project-sites in the remote areas and with the target groups of poor people.

An academic qualification is of prime importance for any position (100\%); employers notify their preferred university or college names, preferred disciplines of education $(30 \%)$, and even identify the class or grade achieved to ensure that only the best-qualified people are employed. For the general developmental jobs, although the academic disciplines are relatively wide, for the specialist-jobs such as medical doctor, nurse, health and sanitary adviser, project coordinator, legal consultant, and technical and vocational training supervisor, employers need a job-contents specific institutional education. For almost all categories of jobs, NGOs prefer past experiences in similar jobs (100\%). INGOs mostly favor experiences gained from government offices, NGOs, public sector, and private business enterprises, largely because they offer projects in collaboration with the government, local administration, private individuals, and national NGOs, and find such experiences very effective.

Job applicants are required to submit a covering letter $(100 \%)$, curriculum vitae $(100 \%)$, educational certificates $(100 \%)$, photograph $(100 \%)$, and experience documents $(46.7 \%)$ along with applications. As it is a common practice in the GOs and FPOs in this country, the NGOs require an applicant to send application handling charges by non-refundable postal order or bank draft.

As NGOs prefer pre-experiences, they do not provide elaborate training and education on employment and before job assignment. Orientation is the most common style of training (100\%) followed by training on activities at the grass-roots level (70\%). Some NGOs encourage recruits and employees to go for self-developing 
education (12\%), and some even give on-the-job training if needed (5\%). BRAC, ASA, Proshika, and other large NGOs place emphasis on professionalism and employ people for a long duration, even up to the retirement age.

Almost all INGOs and many national NGOs offer short-term contractual employment, and most of such contracts span the tenure of the projects for which the employment is made. The job market in the country is fluid, and the opportunity for organized and in-house training is very low. Therefore, experiences in different places increase the employability of a job seeker; and the experienced job seeker can use his/her past experiences to facilitate new employment.

Office work at GOs and FPOs in the country is still mostly done manually. Both domestic large and foreign NGOs however, favor automation of the office and its work, and require staff and managers to possess computer skills, and emphasize proficiency in specific software packages such as, Microsoft Office, Human Resource Information System (HRIS), Databases, and computerized accounting.

Advertisements and notifications provide a clear picture of the responsibilities and duties needed in a particular job (100\%). These contain information on salary, allowances, and retirement and other benefits that the employers will provide (100\%). NGOs in general pay remuneration packages, which include basic salary, annual increment, festival bonus, and contributory provident fund, traveling allowance, pension, and gratuity. For employment in the projects with limited tenure, and especially with foreign fund involvement and collaboration, some NGOs offer gross remunerations (60\%). BRAC, Grameen Bank, and INGOs offer competitive remuneration for employment in strategic positions. BRAC even provides food subsidy allowance, free accommodation, and traveling allowance.

Bangladesh is an agrarian nation, and most of the development activities and target beneficiaries are located in the rural areas and in urban slums. NGOs make clear identification of the locations where an incumbent will be needed to work, and the people they will encounter in their jobs (95\%). Accordingly, they give emphasis on the mental make-up needed for the developmental jobs, and try to understand an applicant's mentality and aptitude during the interview (100\%).

Irrespective of national origins or nature of their functions and mission, NGOs exhibit a strong tendency to employ experienced people (100\%) who can be readily put to work. As such, most of the entry-level training relates to orientation of the jobs to be performed and indoctrination of mission and objectives of the employer, so that staff and employees can commit themselves to achieving those in short- or specified-time framework. Larger national NGOs send their staff and managers for 
training and education in the selected institutes in the country as well as abroad, with funds from the collaborators and donors for such purposes.

Most of the jobs are contractual $(70 \%)$ or limited to the project tenure $(18.3 \%)$. Jobs automatically come to an end as soon as the contracted time is finished. NGOs, which offer similar programs and projects, renew employment or conclude new contracts. For such re-employment, performance in the recent job is given high consideration, and the past experience becomes unimportant or matter of secondary importance. Only the larger NGOs have tenure employment systems, and the competition rate for employment in such organizations is very high.

BARC (BRAC, 2008 \& 2009; Lovell, 1992), ASA, Proshika, and some other NGOs promote equal opportunity or egalitarian employment practices; and people irrespective of religion, gender, and home-district receive equal treatment in the recruitment, promotion, and transfer. The job market for the women in this country is still very undeveloped, but NGOs in general encourage the female job seekers to apply, and Proshika, BRAC, and INGOs play commendable roles to promote employment of females (Khondaker, 2006; Imageshack, 2009).

\section{DISCUSSION AND CONCLUSION}

From this research, we deduce the most characteristic 3-5 features of the 14 sub-domains in the three major areas as follows. In the domain of selection and recruitment, the most important features are very clear job title, presence of personnel management administrative department/section, job advertisements in the newspaper and websites, interview and short-listing of applicants, specification of academic quality for all jobs, submission of curriculum vitae/forwarding letter/diploma and certificate/experience evidence/photograph when applying, contractual rather than tenure employment, possession of job-related pre-experience, possession of job-specific/ general/ communication/language skills, and very clear job description. In the area of training and education, orientation training and grass-roots training are important features. And in the area of compensation and motivation, the most important matters are gross salary, festival bonus, traveling allowance, annual increment, contribution to provident funds, and fixed/clear employment location. Termination or re-employment on the conclusion of contracted tenure is clear, and the possibility of promotion and job re-contract is minimal. Being known in advance, these do not appear to de-motivate job seekers.

It was observed that larger NGOs follow effective personnel management practices, possess adequate organizational personnel management structure and 
professional personnel managers, and nurture a pragmatic environment for modern personnel management. Large NGOs emphasize professionalism and career orientation in management, and implement long-term, forward-looking approaches in their selection, recruitment, and remuneration in order to achieve that. They follow national employment practices, and place due importance on national wage and salary principles, policies, and scales for GOs and FPOs, while still making their own polices and systems. The INGOs, instead of following domestic employment practices, implement policies and practices of their own, which sometimes creates confusion in the domestic job market. Innumerable small and mid-size NGOs do not possess personnel management practices of their own; rather some follow and imitate larger NGOs.

The employment advertisements and notifications show a common characteristic in that all NGOs offer almost similar employment and work conditions, and make those conditions clear in their advertisements and notifications. As development organizations, they want to show their trustworthiness as good employers, who work to emancipate the suffering classes and ensure their prosperity and well-being. Job requirements and processes of application, selection, remuneration, promotion, incentive, training, and education are almost similar across the NGO community, which implies that a uniform personnel management system is rapidly becoming commonplace.

BRAC offers a good example of modern personnel management in the country, and constantly introduces new techniques and methods which induce improvements in personnel management in NGOs across the country. Its current practices encompass elements of personnel management at both FPOs and NGOs/NPOs in the West, and earnestly implement their revision and adjustment in view of the customs and circumstances in Bangladesh. Instead of relying on someone else to develop people's professional skills and hiring such skills from the job market, it is steadily steering its policy to nurture and develop needful skills within its organizational framework, and give importance for the long-term career by these means.

The 57 small NGOs surveyed do not possess any personnel management system or administrative section. Most of their managers are promoters or owners, staff are relatives and friends, and volunteers are non-paid political and local acquaintances and beneficiaries. Most of these NGOs do not employ people for any fixed or contractual tenure. Almost all owner-promoters retain surplus, and do not make any report on receipts and payments and balance sheets. No evidence exists regarding the use of the items under the 14 categories in our checklist. However, several NGOs are found to be 
registered with the government agencies, and in order to comply with the official requirements, they implement a sort of paper-based remuneration system to the executives and partners, and do not have any fixed system of monthly salary payment. A large number of these NGOs are engaged in the so-called micro-credit business, and the profit is allocated among the owner-partners. Two organizations engaged in charitable medical and vocational education were found to have written employment rules. From interviews, however, this was deemed to be the result of its founder's professional background in teaching and research in management. Most of the interviews with the NGO knowledgeable subjects indicate that some of these small NGOs imitate the larger NGOs operating in their areas.

This research is explorative in nature. As the research stands, it has methodical limitation because it relies on simple statistical technique. However, the mixed technique-empirical investigation, practical example, case study, and interview of knowledgeable people, all of which are recognized scholarly approaches-has magnified the findings to a reliable level to elucidate the generally understood shape of personnel management in the NGOs in this country. This mixed technique embarks on the characteristics symptomatic of personnel management practices as found in job advertisements and notices, and proceeds centrifugally to infer, deduce, and develop a general picture. The originality of this research lies also in the fact that this is the first research of its kind on this topic in this country, and thus provides a basic reference framework for further research.

The innovativeness lies in the fact that, although job advertisements and notifications are available in plenty and in any country, researchers fail to realize that these can be scanned to develop an aggregate picture of a personnel management system, its properties, and changes. The authors envision a series of research projects on this topic with focus on its various micro and macro aspects - mission training and indoctrination, incentive and welfare, field staff and volunteer commitment, gender issues, personnel appraisal, organisation development, carrier orientation, employment relations, and behavioral issues, to name a few areas- using more advanced research methods and tools. Most importantly, the authors envisage this research will further encourage examination of NGO-HRM from different quarters, and inclusion of the same in the education program of this country. 


\section{REFERENCES}

ADAB (2000). Directory of NGOs in Bangladesh - Ready Reference 1998-99. Dhaka: ADAB.

Ahmad, M. M. (2007). The Careers of NGO Field-Workers in Bangladesh. Nonprofit Management \& Leadership, 17(3), 349-365.

Alam, S. M. (1998). NGO Kormi: Durgam Pather Sheshe Jey Dekhey Swapner Bangladesh (in Bengali). Aduna, 3(1), 38-40.

Anaheier, H. K., \& Salamon, L. M. (1998). The Nonprofit Sector in the Developing World: A Comparative Analysis. Manchester: Manchester University Press.

Armstrong, M. (1992). A Charitable Approach of Personnel. Personnel Management, December, 28-32.

Barros, C. P. (2006). Earnings, Schooling and Social Capital of Cooperative Managers. Annals of Public and Cooperative Economics. 77(1), 1-20.

Barros, C. P., \& Gomes Santos, J. C. (2003). Earnings and Schooling of Cooperative Managers. Annals of Public and Cooperative Economics. 74(3). 349-364.

Begum, R. (1993). Women in Environmental Disasters: The 1991 Cyclone in Bangladesh. Focus on Gender, 1(1), 34-40.

Birchall, J., \& Simmons, R. (2004). The Involvement of Members in the Governance of Large Scale Co-operative and Mutual Business: A Formative Evaluation of the Co-operative Group. Review of Social Organisation, 62(4), 478-515.

BRAC (2008). BRAC Annual Report 2008. Dhaka: BRAC.

BRAC (2009). Brac. BRAC Website. Retrieved June 2, 2009, from http://www.BRAC.net/.

Butler, R. J., \& Wilson, D. C. (1990). Managing Voluntary and Non-profit Organisations: Strategy and Structure. London: Routledge.

Byrd, J., \& Hickman, K. (1992). Do External Directors Monitor Managers? Evidence from Tender Offer Bids. Journal of Financial Economics. 32(2), 195-221.

Cornforth, C. (2004). The Governance of Cooperatives and Mutual Associations: A Paradox Perspective. Annals of Public and Cooperative Cooperatives. 75(1), 11-32.

Cunningham, I. (1999). Human Resource Management in the Voluntary Sector: Challenges and Opportunities. Public Money and Management, 19(2), 19-25.

Cunningham, I. (2001). Sweet Charity! Managing Employee Commitment in the UK Voluntary Sector. Employee Relations. 23(3), 226-239.

Daily Ittefaq, The (2009). Proshika's Quazi Faruq files case challenging decision of governing body. May 26. 
Daily Janakantha, The. (2006). Grameen Bank - Employment notice. September 15.

Drucker, P. F. (1992). Managing the Non-profit Organization. New York: HarperCollins.

Farrington, J., \& Bebbington, A. (1993). Reluctant Partners? Non-governmental Organizations, the State and Sustainable Agricultural Development. London: Routledge.

Farrington, J., \& Lewis, D. J. (1993). Non-government Organizations and the States in Asia - Rethinking Roles in Sustainable Agricultural Development. London: Routledge.

Fletcher, K. (1992). Effective Boards: How Effective Directors Define and Develop Them. Nonprofit Management and Leadership, 2(3), 283-293.

GOB/MOL (1965). The Factories Act, 1965. Dhaka: GOB/MOL.

Goetz, A. M. (1995). Employment Experiences of Women Development Agents in Rural Credit Programmes in Bangladesh: Working Towards Leadership in Women's Interests. Brighton. U. K.: Institute of Development Studies.

Goetz, A. M. (1997). Managing Organisational Change: The 'Gendered' Organisation of Space and Time. Gender and Development, 5(1), 17-27.

Gosh, C., \& Sirmans, C. F. (2005). On REIT CEO compensation: Does Board Structure Matter? The Journal of Real Estate Finance \& Economics. 30(4), 397-428.

Hashemi, S. M., and Hossain, Z. (1995). Evaluation of Knowledge and Skills of Field Level Workers of Health and Family Planning Programmes. Dhaka: Ministry of Planning, Population, and Evaluation Unit, GOB.

Holloway, R. (1998). Supporting Citizen's Initiatives: Bangladesh's NGOs and Society. Dhaka: University Press Limited.

Hudson, M. (1999). Managing without Profit. London: Penguin.

Imageshack (2009). NGOs Job Advertisements. Retrieved August 23, 2009, from http://img.imageshack.us/.

Khan, S. (2003). PFA and NAP Implementation in Bangladesh: Role of NGO. Dhaka: NCBP.

Khondaker, M. R. (1997). Japanese Style Management for Bangladesh Public Sector The Case of Jute Industry. Dhaka: NSU-NFU.

Khondaker, M. R. (2006). NPO Sector in the Economy of Bangladesh - Historical Development, Present Conditions, and Future Outlook. Academia, 82, 343-383. 
Khondaker, M. R., Bhuiyan, M. S., Runa, L., Khanam, S., Nahar, K., Hossain, A, \& Khoda, Q. (2007). Micro Credit, Grameen Bank, and Developmental Perspectives and Issues in Bangladesh. Nanzan Management Review, 21(3), 209-236.

Khondaker, M. R., Molla, R. I., \& Rahman, T. (2008). A Nomenclature Theory for NGOs in Bangladesh - Lessons from Theory of NGO Commons. Proceedings of the $25^{\text {th }}$ Annual Conference of the Euro-Asian Management Studies Association (EAMSA), 4-6 December 2008, Kyoto: Doshisha University.

Legge, K. (1995). Human Resource Management: Rhetorics and Realities. Basingstoke: Macmillan Business.

Lovell, C. H. (1992). Breaking the Cycle of Poverty - The BRAC Strategy. Dhaka: University Press Limited.

Low, C. (2006). A Framework for the Governance of Social Enterprises. International Journal of Social Economics. 33(5/6), 376-385.

NGOAB/GOB (2009). NGO Affairs Bureau, Prime Minister's Office, Bangladesh. Retrieved June 16, 2009, from http://www.ngoab.gov.bd/.

Nobusue, K. (2002). Bangladesh: A large NGO Sector Supported by Foreign Donors. In S. Shigetomi (Ed.), The State and NGOs - Perspectives from Asia. Singapore: Institute of Southeast Asia.

Oster, S. M. (1995). Strategic Management for Nonprofit Organization - Theory and Cases. Oxford: Oxford University Press.

Ott, S. (2001). The Nature of the Nonprofit Sector. Boulder, Colorado: Westview.

Potter, D. M. (2009). Translational Accountability as a NGO management Issue: Thoughts from the Experience in Bangladesh. Keynote Speech given at the Third Bangladesh Forum at Nanzan University. Good Management, Administration, and Governance for Economic Prosperity in Bangladesh. Nagoya: School of Business, Nanzan University, January 31.

Potter, D. M., \& Ahmed, S. (2005). NGOs and transnational accountability in Bangladesh. Unpublished document, Nanzan University, Nagoya.

Prothom Alo, The. (2009). Save the children USA - vacancy announcement. Saturday, April 4, Dhaka.

Ray, J. K. (1983). To Chase a Miracle - A Study of the Grameen Bank of Bangladesh. Dhaka: University Press Limited.

ROC/GOB (2009). Registrar of Joint Stock Companies and Firms, Government of Bangladesh. Retrieved June 21, 2009, from http://www.roc.gov.bd/. 
Rosenstein, S., \& Wyatt, J. G. (1990). External Directors, Board Independence, and Shareholder Wealth. Journal of Financial Economics. 26, 175-191.

Siddiqui, T. (1996). Interactions between International Financial Institutions and the Non-governmental Organizations in Bangladesh. In A. Kalam (Ed.), Bangladesh: Internal Dynamics and External Linkages. Dhaka: University Press Limited.

Stiles, K. (2002). International Support for NGOs in Bangladesh: Some Unintended Consequences. World Development, 30(5), 831-846.

White, S. C. (1991). Evaluating the impact of NGOs in rural poverty alleviation: Bangladesh country study. ODI Working Paper, 50, London: ODI.

Wilson, A., \& Pimm, G. (1996). The Tyranny of the Volunteer. Management Decision. 34(4), 24-40.

Yunus, M. (2000). Banker to the Poor - The Autobiography of Mohammad Yunus, Founder of the Grameen Bank. Dhaka: University Press Limited.

Zacharias, L. (2003). Small change. People Management, May 1, 24-27.

Zimmeck, M. (1998). To Boldly Go: The Voluntary Sector and Voluntary Action in the New World of Work. London: Royal Society of Arts. 
